\title{
Claude Sernet in the Avant-Garde: Itineraries from Romania to Paris ${ }^{1}$ Michel Gourdet
}

\begin{abstract}
Discontinuité, 1928, Orbes, Ligne de Cour, Le Mail, Transit, Chantiers, etc., constituent des documents du plus grand enseignement. Ce sont elles qu'il faut consulter dès que l'on s'intéresse aux forces inconnues qui vont jaillir. Une œuvre achevée nous livrerait une pensée, des personnages déjà recréés et transposés. Ici, nous sommes plus près de l'âme; c'est la jeunesse qui parle; nous n'avons qu'à écouter sa confession.
\end{abstract}

(Léon Pierre-Quint 17)

Discontinuité, 1928, Orbes, Ligne de Cour, Le Mail, Transit, Chantiers, etc. are most instructive documents. They are the ones that should be consulted when one is interested in unknown, emerging forces. A completed work would provide us with thinking and characters already recreated and transposed. Here we are closer to the soul; it is youth who speaks; we need only hear their confession.

Early in the twentieth century, Romanian artistic milieux were seized with unusual excitement. The country was reexamining both established models and traditional cultural forms. Romania was situated at a distance from the great European artistic and cultural centers (Paris, Milan, Berlin, Brussels, Vienna), but thanks to the railroads and postal system, Bucharest maintained contact with all the innovative artists of Europe. Artists were fully aware of the currents constructing modern art at that time.

One main reason for the artistic and cultural effervescence was the newness of the state. While modern Romania had been created in 1859 by Prince Cuza, the

1 An earlier version of this article was posted on Academia.net under the title "Claude Sernet, l'homme et l'oeuvre."

Dada/Surrealism No. 20 (2015) 
peoples of this Central European state had to wait nineteen more years before its borders were formally recognized by the Congress of Berlin in 1878.

For Europeans, Romania seemed distant, rural, traditional, and nationalist, a country where, as in many areas of the Balkans, a particularly receptive youth was on the move, enthusiastically constructing different tastes, a new identity, and a culture of disruption to usher the country into the twentieth century.

In Târgu Ocna, located in eastern Romania, where, it can be said without exaggeration, almost nothing ever happened, a baby boy named Ernest-Benoît Spirt was born on 24 May 1902. He was the son of a physician in a small, still very agrarian town located in the northeast at the foot of the Carpathian Mountains. Far from Iaşi, the large university city of the north, and even further from the noisy capital Bucharest, the Spirt family lived in what was a modest, half rural, half artisanal village, where his father had come to establish his practice after finishing medical school.

During his childhood in the Carpathians, the boy might have known a life rhythmed by the calm succession of days, the movement of animals, and the passing of seasons. However, in this part of Europe, certain men, like scientists growing cultures of virulent microbes in laboratories, were already experimenting on a small scale with a number of the political, ideological, and cultural dramas that the European continent would see produced on an industrial scale later on. As the oldest son of a family of Jewish and peasant origins that had managed to emancipate one of its own in a Romania just emerging from feudalism, the young Ernest Spirt faced symbolic, social, and political violence at an early age. His birth in a country subject to peasant revolts and bristling with intercommunal hatreds would indelibly mark his personality. Twenty-three years later, in Paris, Ernest would, through an anagram of his given name, take on the pseudonym Sernet.

In the meantime, however, certain fundamental European values had difficulty gaining a foothold in Romania. Behind its indolent façade, the country was in full development. But it was also one of the first countries to be struck by a terrible wave of scientifically distilled intolerance and hatred, especially after World War I. For a month and a half in spring 1907, a violent peasant revolt, the last in Europe, had inflamed Moldavia, causing several thousand deaths. The Russian tradition of pogroms was still very much alive in Romania. And so, during his childhood, young Ernest experienced hasty flights deep into the countryside to escape from outbreaks of anti-Semitism that rocked the cities.

Ernest's father Dr. Spirt loved work and study above all else. Outside his medical practice and a life that didn't fully suit him, he penned articles for medical journals while also preparing a history of medicine. He was already thinking of moving to Bucharest, which the writer Paul Morand described as follows: "Capitale d'une terre tragique, où souvent tout finit dans le comique, Bucarest s'est laissé aller aux événements sans cette raideur, partant sans cette fragilité que donne la colère" (291) 'Capital of a tragic land, where everything often ends in the 
comical, Bucharest was letting itself be carried by events without that resistance, and hence brittleness, that comes from anger.'

In this childhood, cries and fury resonated even more strongly in contrast to the calmness and predictability of daily life. In 1907, the family expanded with the birth of Ernest's sister Colomba. In 1913, young Ernest was sent to the high school in Iaşi to continue his studies. There, he met Ilarie Voronca, who would later become his brother-in-law; it is there that he also discovered French literature. Spirt's French professors were fervent connoisseurs of symbolist poets, having been educated on the critical works of Romanian specialists on French symbolism, Nicolas Iorga and Nicolae Ion Popa. Intellectual circles were taken by this literary current, a vehicle for powerful images, and by the work of visionary poets and travelers like Gerard de Nerval, which opened up new aesthetic possibilities.

Spirt was not yet writing in French, but in a few years his art poétique would carry traces of this early encounter with French symbolist poets, and with Nerval in particular. His early work bears the marks of these discoveries, as we see in this 1927 poem, titled "Vieux temple" (Old Temple):

Réveil d'une aigre enfance où roule un bruit de chaînes Amour puni d'attente, espoir sans désespoir Pour que rien n'en demeure au ciel des nuits prochaines Le temps reprend sa flamme et l'offre au deuil des soirs (Les pas recomptés 19)

Awakening from a bitter childhood where rolls a noise of chains Love punished with waiting, hope without despair So that nothing remains of it under the sky of next nights Time recaptures its flame and offers it to vesperal mourning.

For adolescent Spirt, the realm of poetry had more immediate pull than all of men's bloody conflicts. A few years later, in notes written in Pavia, he would stress this "Grande Nuit au milieu de laquelle je suis né" 2 'Vast Night in which I was born.' After the Second World War, he once again would return to this specific situation in Romania in the prefaces written for L'Exode by Benjamin Fondane and Premiers poèmes by Tzara.

The scandalous differences in treatment to which some people were being subjected at that time marked an entire generation. The Romanian university, in particular, was still making use of the "ghetto bench," which ostracized Romanians of Jewish origin. Many men and women coming to France from this far-off European province would long carry the imprint of these difficult formative years on their conscience as artists and citizens. This situation would often find

2 Manuscript notes by Claude Sernet, provided by Colomba Voronca, qtd. In the author's thesis, p. 13. The current location of these notes is unknown. All further references to these notes will be cited as "Notes," with page references to quotations in the author's thesis. 
expression in the work of writers such as Benjamin Fondane, the poet, screenwriter, and philosopher who later developed the concept of conscience malheureuse (unhappy conscience); Ilarie Voronca, who became the great tragic poet of crowds and brotherhood; and of course, Ionesco, the famous playwright of Rhinoceros, the great pioneer of the theater of the absurd.

\section{First Passage}

In 1913, Romania engaged in war against Bulgaria. In 1916, King Carol I declared war on Germany. Early in the conflict, Sernet's father was seriously wounded and Romania was split, with two thirds of the country being occupied by the Central Powers. Brutally separated, Sernet's family was suddenly plunged into grief and poverty. In 1920, the family was reunited once again. They finally moved to Bucharest, where Ernest, now a high school graduate, enrolled in law school upon his father's advice.

In the feverish activity of the capital, the young poet met artists who lived, hoped, and expressed themselves like an avant-garde. Like any Romanian student, the young Spirt was by now very familiar with the French language, literature, and writers. In a country undergoing rapid economic, social, and political transformation, young intellectuals eagerly adopted the literary modernity coming from France, with its audacity, revolt, and formal experimentation.

Spirt began to write subjective poems in free verse; like all the Romanian literary youth, he was also familiar with the meteoric Demetru Demetrescu-Buz Buzău, a strange writer better known by his literary pseudonym Urmuz, whose work, infused with black humor, nonsense, and the absurd, influenced all those who wanted to question norms, rules, and established practices. Thanks to young writers' cultish devotion to him, Urmuz exercised a substantial influence on the Romanian avant-garde, which considered him an iconic predecessor. His name and his few written works were often cited in the pages of Romanian dadaist, constructivist, and surrealist journals that came and went regularly during that period: Flacăra (The Flame) edited by Ion Minulescu, Simbolul (The Symbol) created by Tzara and Janco, Sburătorul (The Sylphe of the Air), Punct (The Point) directed by Scarlat Callimachi with the participation of Victor Brauner and Stephan Roll, Contimporanul (The Contemporary) edited by Ion Vinea, and 75 HP.

Launched by the painter Victor Brauner and the writer Ilarie Voronca, $75 \mathrm{HP}$ claimed to be resolutely constructivist. Its dynamic, modernist, metaphorically expressive, and "explosive" title (HP is the abbreviation for the unit of measure for steam power) expressed this young generation's fascination for all forms of modernity. As early as 1924, this review was increasing Romanian familiarity with other European avant-garde reviews such as Abstract, G, Merz, and Der Sturm. It also announced the upcoming inauguration of other new Romanian journals like 
Integral, and a little later, unu, which, under the direction of Saşa Pană, would be one of the few to remain in existence for eight years (April 1928-September 1935).

Spirt's father viewed his son's sudden penchant for the literary life with a disapproving eye, and the young Sernet would only participate from a distance in the activity of the multiple and fluid groups who gave life to these ephemeral publications. $75 \mathrm{HP}$ was the first review to which he made a modest contribution, signed with the pseudonym Mihail Cosma. Writing in French and embracing the fervor of the Romanian avant-garde, Sernet was already expressing a dadaist disdain for all the arts, and especially literature.

But history was rumbling in Romania where, under the influence of the bloody "green shirts" of the fascist activist Codreanu, the political climate was growing more tense each day. In Bucharest, the university bullying in reaction to Spirt's Jewish origins increasingly weighed on him. Heeding his father's advice he, like many others, left Romania and in 1925 enrolled in law school at the University of Pavia to complete studies that might open the door to a profession in law.

Alone in Italy, a country that had just undergone a fascist revolution, it was only through reading that Sernet could continue to refuse established artistic values and feed his personal revolt. He read the futurists, in particular Paolo Buzzi, while maintaining a regular correspondence with friends still in Bucharest, as well as with those already living in Paris.

In 1926, he traveled to Paris for the first time while on summer vacation. There, he was reunited with Romanian friends, including Benjamin Fondane, as well as his sister and brother-in-law Ilarie Voronca who, like Sernet, had come to discover the French capital.

Editor-journalist Denys Paul Bouloc, who knew these poets of Romanian origin well, noted after the war that Voronca "était un poète total, c'est-à-dire un sage et un magicien. La poésie lui tenait lieu de religion; il ne croyait vraiment qu'en elle. Et c'est pourquoi, dans sa perpétuelle exaltation, il estimait que le poète est en toute circonstance concerné" (21) 'was a total poet, that is, a sage and a magician. For him, poetry was a religion; it was the only thing he truly believed in. And that is why, in his perpetual exaltation, he felt that all things were of concern to the poet.'

Like his brother-in-law, Sernet was above all a poet in love with words, a Romanian fascinated by the powers of the French language, a man who loved to be free and who placed his hope in brotherhood, while seeking to "figure out" the world. In a later poem, his brother-in-law Voronca described this intention to command the world's respect:

C'est vers vous, hommes de l'avenir

Que va ma pensée.

Et je veux que vous vous exclamiez

"Il était des nôtres", quand vous lirez mes poèmes.

(La poésie commune 27) 
It is toward you, men of the future

That go my thoughts

And I want you to exclaim

"He was one of ours" when you read my poems

For those sometimes referred to as "The Romanians of Paris," the capital meant the Montparnasse neighborhood. There, Sernet met young artists who were often foreigners like him. His contact with them, and especially his first encounter with the young Arthur Adamov, transformed his sheltered life as law student. Fascinated by the activity in Paris, he returned to Pavia with books one clear conviction: he would not become a lawyer. During his stay in Paris, his life had taken on meaning: he would become a poet.

While finishing his thesis, he resumed his Italian exile on the banks of the Ticino. He read and carefully annotated the Petit Manuel du parfait aventurier ( $A$ Handbook for the Perfect Adventurer) published in 1920 by the eclectic writer Mac Orlan. Later, Sernet remarked in his notebooks, "Ma jeunesse à moi, ce furent plutôt l'envie, la passion, le rêve de voyager qui l'ont formée" (Notes) 'As for my youth, it was shaped more by my desire to travel, my passion, my dream.'

His imagination kindled, Spirt created his pen name; becoming Claude Sernet, he decided to write only in French. During this time, he noted:

Vivant en marge de la vie. Seul, en marge de la solitude. Révolté, en marge de la révolution. Rêvant, en marge du rêve. Pensant, en marge de la pensée. Ignorant, en marge de l'ignorance. Mort (mourant) en marge de la mort (le seul domaine qu'il me soit permis comme paria: la zone en marge de tout.). L'état de paria n'est pas nécessairement un en dessous il est surtout un en dehors. (Notes 32)

Living on the margins of life. Alone, on the margins of solitude. Revolting in the margins of revolution. Dreaming in the margins of dreams. Thinking in the margins of thought. Not knowing in the margins of ignorance. Dead (dying) in the margins of death (the only area that is allowed me as a pariah: the zone in the margins of everything). The state of pariah is not necessarily an underneath-it is especially an outside.

For a time, Sernet traveled between Paris and Bucharest, long enough to win over his family. Then, following the example of other Romanian friends, he decided to settle permanently in Paris. As the critic John Kenneth Hyde notes, "Hence for Fondane, as for many of his contemporaries, the removal to France was in many respects a physical closing of the gap that had been effected years earlier in the intellectual sphere" (13). 


\section{Settling into a Language and a History}

Almost ten years after the end of the First World War, the literary milieux of the French capital had changed considerably. Dada had been buried in 1924, and surrealism would gradually lose its edge. The little literary world was calming down some. Provocations came less frequently and the artists had grown both more serious and more politically engaged. The golden age had already passed. At twenty-five years of age, Sernet found himself frequenting artists considerably older than he and deeply involved in their literary career. Aragon, Breton, Duchamp, Éluard, Tzara, Picabia, Ribemont-Dessaignes, and others like them were all over thirty years old.

Having entered its ideological phase, surrealism had left to the Centrale surréaliste the job of pursuing systematic explorations of the "Merveilleux." Sernet, too young to have been seared by the First World War, still fostered a strong spirit of revolt, like any good avant-gardist. However, his revolt would never adhere completely to that of his elders. Because of his youth, origins, cosmopolitism, separations, lack of ideological or religious engagement, and precarious living conditions in France, Sernet was drawn more to the very young members of a new avant-garde group that was attempting to carve out its own space alongside the surrealists. He frequented René Daumal, Roger-Gilbert Lecomte, Roger Vaillant, and Robert Meyrat, poets who called themselves the "Phrères simplistes" (Simplistic Brothers). These young men had just arrived from Reims to create a review titled Le Grand Jeu, which would become famous. With the help and collaboration of other artists like Joseph Sima, Pierre Audard, Andre Delons, Artür Harfaux, Maurice Henry, Benjamin Fondane, Pierre Minet, and André Rolland de Renéville, the newcomers on the Boulevard Montparnasse determined to contest the legacy of surrealism with the backing of editors Jean Paulhan and Léon Pierre-Quint.

The history of the avant-gardes took off anew with these poets whose explorations and theoretic and literary work focused on the mystery of the poetic experience understood as a form of mysticism, a path of metaphysical research. But once again, time passed too quickly. Sernet, like all those whose time seemed limited, tried to adapt to this already changed artistic and literary environment. Paris was less electrified by tracts, manifestoes, torrents of books, and ideological engagement. France was moving toward the terrible year of 1929 and the ripples of the Great Depression. Life was becoming more difficult for foreigners in Montparnasse. And yet, creativity, activity, and research continued in a Paris unaware of the gathering clouds. The city still breathed noisily in the midst of a frenetic concentration of young men and women from all over the world who had come to "camp" in the cafés of Boulevard Montparnasse and especially at the mythic Dôme. There, Sernet found, "des hommes dont la seule recherche est une évidence absolue, immédiate, implacable" "men for whom the search alone is an immediate and implacable absolute.' 
Like many others, Sernet lived in a hotel on rue de Cronstadt. His neighbors were Adamov, as well as painters of Romanian origin: Jacques Hérold, Victor Brauner, and Michonze (the latter from Bessarabia). He eked out a living in a neighborhood where artists such as Soutine, Archipenko, and Chagall had preceded him. Another fellow Romanian, the sculptor Brancusi, worked nearby on Impasse Ronsin. Unknown to the surrealists, this neighborhood near the immense slaughter houses of Vaugirard became the crucible of a true diaspora of intelligence, mostly from far-off Central Europe. As Georges Navel, another pariah (of French stock) noted, the residents of this neighborhood could marvel "à voir les visages d'une jeunesse venue de tous les pays du monde" (116) 'to see these faces of a youth from all parts of the world.' In the cafés on Boulevard Montparnasse, Sernet developed a relationship with other little-known artists such as Henri Calet, Jean Carrive, Monny de Boully, Fernand Lumbroso, and Roger Vitrac who were unfamiliar with the more subdued cafés of Boulevard Saint-Germain or Place Blanche.

Thus for Sernet, everything came together in what his friend Arthur Adamov later called, "cet invraisemblable campement" (L'Homme et l'enfant 33) 'this unlikely encampment.' Still poor, Sernet worked on his poems in a small maid's room overlooking Léon Guillot Square. He also produced numerous literary works on commission - theses, articles, translations - which allowed him to survive. It is in this same neighborhood that all would come to an end for him on 15 March 1968, shortly before his sixty-sixth birthday. But for the moment, it is from this address, from these encounters, from this slowly maturing activity, that the members of a small group of acquaintances, at Adamov's initiative, decided to act, in February 1928, bringing the meteoric journal Discontinuité to fruition.

Arthur Adamov was only twenty years old. He had just failed his "entrance exam" into the surrealist group. Having thrown himself headlong into the poetic and literary adventure, he bubbled with audacity and activity along with SergeVictor Aranovitch, his friend from middle school who was starting his studies at medical school. Pushed by Adamov, who was already attracted to the theater, Sernet, along with his few foreign friends, agreed to give a first artistic performance to make himself known to the general public. This kind of manifestation, a forerunner of our modern "happenings" and performances, had become common in avant-garde circles. Sernet's friend Tzara, the Romanian "father" of Dada, had started this trend at the Cabaret Voltaire in Zurich in 1916, and the surrealists adopted it later on. The Adamov-Sernet "tandem" planned to give three performances at the Studio des Ursulines on 18 February, 3 March, and 17 March 1928.

Run by actor Armand Tellier, ardent supporter of the avant-garde theater and cinema, the Studio des Ursulines had been home to the intellectual elite of the Latin Quarter since 1925. Dadaists and surrealists like André Breton, Man Ray, Fernand Léger, René Clair, and Robert Desnos, as well as Marc Allégret went there frequently. Everyone who loved scandal and the cinema frequented this theater. 
There, in 1926, Marcel Duchamp showed Anemic Cinema, in which a series of pataphysical calembours turned upon a series of rotating discs: the "rotoreliefs." The screening ended in a fight. The same year, his accomplice Man Ray, who had launched the New York "branch" of the Dada movement with Duchamp in 1921, presented Emak-Bakia, or "Leave me alone" in Basque, a sort of cinépoème, at the Ursulines. Also there, in 1928, Man Ray screened Les Mystères du château de Dé, produced by his friends Marie-Laure and Charles Vicomte de Noailles and filmed in Hyères in their cubist villa, the masterpiece designed by architect Robert MalletStevens. Man Ray would present yet another film at the "Studio": L'Étoile de mer, based on a scenario by Robert Desnos, directed by the avant-garde photographer Jacques-André Boiffard, and starring Kiki de Montparnasse, Man Ray's companion and celebrated muse of the avant-garde artists. On February 9, 1928 The Studio des Ursulines also saw the premiere screening of La Coquille et le clergyman (The Seashell and the Clergyman), Germaine Dulac's first film, based on a scenario by Antonin Artaud, which was disrupted by heckling by the surrealists led by André Breton and Louis Aragon.

So the theater was famous. Sernet and his friend planned a program to launch the poetic and musical performance that would make a name for them. The publicity flyer announced the event in the form of a poem:

MUSIQUE PAR BEERS GILBERT, MAXIME JACOB \& SAUGUET

TABLEAUX DE WLADIMIR SHWAB.

PIANO OPTIQUE DE BARANOFF ROSSINE

UNE MISE EN SCENE DE MEDGYES

UNE PI ÈCE DE ROGER VITRAC

MAINS BLANCHES DE AR ADAMOV

QUELQUES ESSAIS DE MAN RAY

5 MINUTES DE CINEMA PUR PAR CHOMETTE

DES FRAGMENTS DE FILMS INÉDITS

DES PO ÈMES DE CLAUDE SERNET ET

DE QUELQUES AUTRES

LECTURE DE SCÉNARIOS ET DE FATIGUES

PHOTOGRAPHIES

Music by Beers Gilbert, Maxime Jacob \& Sauget

Paintings by Wladimir Shwab

Optic Piano by Baranoff rossine

Staging by Medgyes

A play by Roger Vitrac

White hands by Ar Adamov

A few experiments by Man Ray

5 minutes of pure cinema by Chomette

Fragments of new films

Poems by Claude Sernet and 
several others

A reading of scripts and lassitudes

Photographs, photographs

Avant-garde Paris was accustomed to this type of event that no longer "shocked the bourgeois." However, during the eclectic artistic event in this theater, celebrated in avant-garde circles, this group of mostly "montparnos" was rather well-behaved. Sernet and Adamov no doubt hoped that the energy and the reputation of the site would help them realize their artistic hopes and attract the attention of critics. Unfortunately, from its very first performance, the event was a failure and, contrary to their hopes, their literary breakthrough would not happen that afternoon.

Four months later, in June 1928, Adamov and Sernet succeeded in editing a short-lived journal titled Discontinuité, published shortly before the first issue of Le Grand Jeu. Discontinuité was printed in black front and back in a 20x27 format; its editors were Arthur Adamov and Claude Sernet. It was housed at 33 rue de Cronstadt, Paris 15e, the address of the hotel in which Adamov resided. The editors managed to sell two pages of advertisement to two publishing houses associated with the avant-garde. The first to back Discontinuité was Éditions Kra, whose prestigious editors were André Malraux, Léon Pierre-Quint, and Philippe Soupault. Earlier, in 1924, they had published Breton's Manifeste du surréalisme. The second publisher was Sans Pareil under the direction of René Hilsum, who published Soupault, Breton, Aragon, Picabia, and Cendrars.

The single issue of Discontinuité cost 3 francs, or one quarter of the price of a book published by Sans-Pareil. Besides Sernet and Adamov, the table of contents included Serge-Victor Aranovitch, Monny de Boully, Victor Brauner, Jean Carrive, Benjamin Fondane, Fernand Lumbroso, Georges Malkine, Dida de Mayo, Grégoire Michonze, Georges Neveux, and Man Ray.

On page three, the review opens with a text titled, "L'Aube n'est pas une épée" (Dawn is not a sword), signed by a group called "Discontinuité." This striking opening, with its sybilline conjunction of terms in the surrealist spirit, is meant to jolt the reader and prove their originality. Most likely conceived by Adamov, the manifesto-like text makes several raw declarations: "Aujourd'hui plus que jamais, nous tournons dans un magasin d'agonie d'où nous désespérons de sortir. . .." 'Today more than ever, we turn in circles in a store house of agony, from which we despair of ever escaping' and, "En vérité, nous savons que rien, absolument rien ne vaut la peine d'être joué" 'In truth, we know that nothing, absolutely nothing is worth venturing.'

The premise of this text centers on the expression of a powerful difficulty of living existential malaise in the face of which the signatories confess their powerlessness. "Notre vie," they declare, "n'est en somme, qu'une question de mise au point" 'Our life is merely a question of constant adjustment.' The text concludes on this peremptory declaration, "Il ne nous reste rien" 'There is nothing left for us.' This text acts as a collective story written in the first person plural. The 
"nous" (we) punctuates the text like a leitmotif. Symbolically, it represents the group of artists who participated in the adventure of this first issue. It highlights their way of relating to a time lived, as the saying goes, "au jour le jour" 'one day at a time,' that is, discontinuously in both phenomenological and existential terms. The collective first person also allows them to take stock elliptically of their engagements in the service of the avant-garde, the disruptions of their youth, their hopes, and the ups and downs of their difficult lives. They do not define this discontinuity, which, in closing the text, functions as a diacritic sign, its own signifier, laying out the non-linearity of life. This ubiquitous "we" also allows the drawing up of a list of situations which, acting as major obstacles, end up introducing and provoking a deep and ambiguous existential malaise in the ethos of each member the group. This "nous" continually intertwines the painful memories of their failures as stateless people with the tension of their hope as avant-garde artists to whom recognition and success seemed constantly denied.

The title of this true-false manifesto, just like the discontinuity-continuity of the text's signature, then reveals its meaning. The reader must understand what is said in both senses; the reader must - and must not - accept the overall ambiguity that makes both the text and the collective "nous" work, the "nous" who are telling a story and telling their own story in a symbolic narrative. The rich language with its series of symbolic images is there to illustrate - and not illustrate - each step of their convergent individual paths and their collective divergent movement. This text is - and is not - what it is, and it is also something else.

"L'Aube" 'The Dawn' of the avant-garde, so new to them, "n'est pas" 'is not' a dawn - a moment of hope -nor is "l'épée" 'the sword' of words, art, the verb, poetry, which they had thought could be used to achieve their poetic destiny, solely an object, an offensive or defensive weapon. The whole of this text functions like a dictionary entry that would say both what is - and what is not - an avantgarde. This text is the extended metaphor of their philosophical and aesthetic system.

\section{Rimbaud finally finds his brothers}

In contrast to collaborators on other surrealist journals, even Le Grand Jeu, most of the artists participating in this first and only issue of Discontinuité were of foreign origin. Emigrants, stateless people, fugitives, and exiles coming from Serbia, Romania, Russia, the United States, or from some distant diaspora; their alliance, though they sensed that it would be short-lived, also perfectly embodied this principle of discontinuity that they had chosen as the emblem for their group. In the densely-printed two-columned pages of this sixteen page issue, they give concrete form, phenomenologically, to their common experience of disruption. The pages contain an apparent pell-mell of short poems, some in free verse, poetic and philosophical prose, provocative titles, surrealist images, enigmatic assemblages, and flash-words. Slipped in among the written contributions are 
several snapshots, which seem to illustrate the pages of this first issue. Arranged in the margins of the texts are four unsigned black-and-white photographs, as well as reproductions of four paintings and one rayogram by Georges Malkine, Victor Brauner, Michonze, Dida de Mayo, and Man Ray.

Other rather ordinary, unsigned photographs function somewhat like the chance (and symbolic) encounters in Lautréamont's mythical Chants de Maldoror. Seemingly insignificant amateur photographs, these images are simple snapshots: a woman's shoe abandoned on a forest path; a stocking covering a leg cut off by the frame; an ambiguous portrait of either a "garçonne" or a boy; the head of a mannequin covered with an enigmatic flowered cap. Together, however, these photographs embody the absence/presence of connections; they signal that beyond the fundamentally discontinuous character of the real, which they reveal, there exists between them a sort of continuity potentially bearing meaning.

The artist-typesetters of Discontinuité were conscious that their union was neither an end in itself, nor a crucible in which energies stretched to the limit would mix and be consumed as if by fire. The men who participated in Discontinuité were not driven by the desire to carry to term a collective experience imposed by a single person. To better understand the originality of the Discontinuite group within the avant-garde adventure, we can look to the notion of "l'égrégore" as defined by Pierre Mabille, a discrete companion of André Breton. This group had its own identity. It had nothing in common with those who had gone before. Nor did it resemble the movements that would mark French intellectual life after the Second World War. Discontinuité was different because it laid claim to no definitive propositions. Its members played and fought together in solidarity to change the world, and knew that the world had changed them. They understood the paradox of the avant-garde, of the hoped-for change, revolt, modernity and perhaps even the Absurd that would come. Everything was changing and yet nothing was changing. Having arrived a little too late, they also felt they were leaving a little too soon. Though having come to the end of their dreams, they still had not come to the end of the image's possibilities.

Discontinuité marked the end of a certain type of avant-garde; at the same time, it also announced those that would begin emerging at a steady pace. Later avant-garde movements would be more philosophical, political, and scientific. They would be driven by Camus, Bataille, Morin, Serres, and Lupasco. They would integrate new media and assemble individuals in networks less literary and poetic, and much more open to musical, cultural, technological, televisual, and mass electronic forms.

Dada and surrealism were like nervous tissue: rigorous, precise, alive, all shifts in matter coordinated. Discontinuité, on the other hand, was like a block of blood, fragile and unstable, vagabond, with uncontrollable movements. The members of Discontinuité knew how to stay free and live friendship without exclusion. Their affinities made them recognize one another and gather outside political engagements or aesthetic decrees. In Discontinuité, there was no directive power. 
Each individual pursued his own construction at the heart of the acephalous group, all the while contributing to the growth of the others in complete independence. Instead of all for the group as in surrealism, Discontinuité practiced all by the group. This spontaneous and nondirective tentative would last, as do all entities predicated on expenditure of existential forces: the duration of a spark that leaves lifelong memories.

The discontinuity they claimed remains a poorly understood notion. Yet it lies at the very core of the reflection underpinning the work of all the avant-gardes and their precursors. The concept of discontinuity is manifestly present in each aesthetic disruption or newly instituted policy. Discontinuity is a heuristic model that runs through not only the literary field but also philosophy and the political world. It buttressed Rimbaud's Illuminations, and formed the basis for subsequent avant-gardes, such as simultaneism, cubism, futurism, and surrealism. It was present in Bataille's thinking when he declared, "Nous sommes des êtres discontinus, individus mourant isolément dans une aventure inintelligible, mais nous avons la nostalgie de la continuité perdue" (L'Érotisme 21-22) 'We are discontinuous beings, individuals who perish in isolation in the midst of an incomprehensible adventure, but we yearn for our lost continuity' (Eroticism 15).

The disruptions and cracks that affected science and history before the second worldwide conflict rendered this principle more operational than ever. In Russia, Germany, Italy, Romania, and even the United States, all of them vast industrial and cultural laboratories, the old world's continuity wavered, entire swaths of certainty fell. Not long after, Benjamin Fondane rightly observed, "Nous vivons dans un monde discontinu. Les philosophes ont beau vouloir coller soigneusement les morceaux épars, pour éviter de faire voir les ruptures, l'histoire est faite de trous, de fosses... Et de fosses communes" (19-20; ellipses Fondane's) 'We live in a discontinuous world. Philosophers try in vain to carefully paste the scattered pieces to avoid letting the cracks show, but history is made of holes and ditches... And of common graves.' What of today?

What should we retain of all the activities evoked here from the year 1928? We must remember that most of the young people who made up this group were uprooted artists who faced difficult economic, political and social situations in more than one European country. In Paris, their living conditions rarely improved and often remained very difficult. Money was a rare commodity and number of them were seriously in need. Despite their difficult lives, their memory of the mad hope first spread by Dada and later maintained by surrealism remained strong enough to let them dream and await their place in the sun.

Tzara had learned humor in Paris and the surrealists had shown him what the force of intelligence could attain. Discontinuité displayed and staged that which did not yet exist and which a few years later would become the expression of the malaise of European civilization resulting from a sense of ennui generated by the era of crises, the difficulties of armed peace, and the impending conflict both hoped for and reviled. These young artists, who had come to France willingly with 
a number of Romanians in the lead, would be among the first to question the meaning of their existence as human beings. Their sensibilities and experiences paved the way to the dark territory of the absurd, which other Romanians (Emil Cioran, Eugene Ionesco, Ghérasim Luca, and Paul Celan) would implant deeply in French literature after 1945.

But in 1928, on the eve of the first worldwide economic crisis, the artists of Montparnasse proclaimed their right to exist alongside Montmartre, the other hill, where most of the surrealists lived and gathered. More independent, less politically engaged, the bohemians of the Dôme remained hyper-sensitive to demonstrations or signs of xenophobia, exclusion or precarity.

In the crowded Montparnasse neighborhood, Claude Sernet lived in conditions that corresponded to his true character. He wanted to make a name for himself, while remaining pure and faithful to his artistic convictions and aesthetic values. His friends liked to say that this cultured man, expert in poetry, preferred to maintain in their presence the reserve of contemplatives or melancholics.

Early in the summer of 1929, the adventure of Discontinuite came to an end with the publication of a thin pamphlet in 19x11 cm format with a yellow cover and titled Mises au point. In thirty-three pages, Adamov, Lumbroso, and Sernet sum up Discontinuité. In his text, Adamov reminds readers that for him discontinuity is an existential feeling rooted in the very experience of being plunged into the heart of life by the chance of all his adventures. He reflects on what could be done when a lack of money reduces access to the public forum. He returns once again to Discontinuités individual and collective differences with surrealism:

Quant à l'activité révolutionnaire, il nous tarde depuis bien longtemps déjà de nous entendre à ce sujet. Ce que nous nommons ainsi, ce que nous aurions dû faire, ce que nous aurions fait si, au lieu d'être quelques amis, nous eûmes formé un groupe plus considérable, c'eût été non point d'écrire ici des phrases de rhétorique contre la réaction qui s'abat sur l'Europe, - mais manifester. Et lorsque nous disons manifester, nous n'entendons pas 'chahuter' tel spectacle dont l'esprit, même s'il nous répugne, n'est point somme toute à l'opposé du nôtre, mais saboter l'autre, le spectacle hideux et permanent que nous offrent tous les jours, en France comme ailleurs, les bals de bienfaisance, les obsèques nationales de ceux qui l'ont faite et qui la referont, les galas de l'Opéra, les séances de la Chambre, le carnaval macabre des parades militaires, toute la merde enfin, la merde obligatoire et patriotique. (3-4)

As for revolutionary activity, we have long waited to express ourselves clearly on this subject. What we name thus, what we should have done, what we would have done if, instead of being just a few friends, we had formed a larger group, it wouldn't have been to write a few rhetorical lines here against the reaction that is descending upon Europe - but to 
demonstrate. And when we say demonstrate, we don't mean make a spectacle, whose spirit is not really the opposite of ours, even if it repels us, but rather sabotage the other, the hideous and constant spectacle that is offered us every day, in France as elsewhere, by the charity balls, the national funerals for those who have engaged in revolution and will again, the Opera galas, the Parliamentary sessions, the macabre carnival of military parades, in short, all the shit, the obligatory and patriotic shit.

The situation in France had, indeed, changed significantly. The armistice of November 1918 was now in the distant past and forefront of the French political scene was once again becoming a shadow theater given over to domestic and international political problems, to worldwide economic difficulties, and especially to the growth of fascism in Europe.

An examination of the texts in Discontinuité, and of those written by Sernet himself, helps us better understand the literary activity of the Parisian avant-garde groups influenced by surrealism after the death of Dada. The lives and activity of their protagonists are still little known today. However, from this discussion, we can see that their contribution was important and original. The approach of the Discontinuite group was, of course, without hope, but nevertheless anticipatory. Not until much later did Roland Barthes remark that "La discontinuité est le statut fondamental de toute communication" ("Littérature et discontinu" 1306) 'Discontinuity is the fundamental status of all communication' ("Literature and Discontinuity" 181).

\section{Transition and Precarious Passages}

With Discontinuité, Sernet and his friends used their short-lived gathering as a form of protection by refusing to submit to and by resisting any all-consuming and apparently permanent engagement (a poetic model, political parties, a philosophical current, the use of drugs, the cult of the personality, individual poses, or group fashions). This allowed them to preserve their autonomy, their solitude, their anxieties, in a word, their freedom in their vital project. But after the economic crisis and with the rise of the perils that would soon lead to the Second World War, the time of the avant-gardes and of continuous invention was quietly coming to an end.

Nevertheless, in 1933, Sernet opened up a new dimension of discontinuity by editing the fourth issue of Cahiers Jaunes published by Librairie José Corti. For this issue, titled Cinéma 33, Sernet invited numerous longtime friends (Antonin Artaud, Monny de Boully, Luis Buñel, Hendrick Cramer, Robert Desnos, Benjamin Fondane, Roger Gilbert-Lecomte, Maurice Henry, Georges Neveux, Jean Painlevé, Man Ray, Georges Ribemont-Dessaignes) to participate. The issue was devoted mostly to a cinema that had also been in evolution since the arrival of talkies in 1927. Claude Sernet brought together writers, poets, playwrights, filmmakers, screenwriters, documentary filmmakers, and photographers. They all 
shared a deep passion for their work with the aesthetics of the image, for each considered the image the essential means for gaining insight into man, poetry, emotion, art, the world, and life.

This publication acted as a final statement at a crucial point in time when Sernet and his friends once again perceived the dramatic transformations in "un monde dont la faillite, aujourd'hui plus que jamais, nous paraît inévitable" (Cinema 33 3) 'a world whose collapse seems inevitable to us, today more than ever.'

In this issue dedicated to the cinema, they sought to investigate the place, function, production, use, and impact of the images that had been the "cement" of the avant-gardes. The eternal quest for images had been with humanity since its origins. Images had inevitably accompanied the birth of the many human cultures like mothers. People had never stopped producing, maintaining, questioning, destroying, or making them live and act in their dreams, myths, or legends. Painting, sculpture, poetry, novels, song, photography, journals, and finally cinema had created an infinite repertoire of images.

As artists of the avant-garde, the participants of this thematic issue were familiar with images. They had learned to watch for their genesis, to imagine the best way to construct and assemble them. They had worked them, constantly bringing them into play, juxtaposing them, and interchanging them to provoke the many emotions which for which they were most effective medium. They had learned to master their symbolic powers to enhance their meaning. In this issue, the thirteen authors from all areas of art wanted to analyze fixed and moving images one last time by examining them "passer à travers le prisme de trois spectres: P[H]AMPHLET [sic], METAPHYSIQUE, POÉSIE - seuls actes valables de l'esprit en marche" (Cinéma 33 4) 'through the prisms of three forms: Pamphlet, metaphysics, poetry - the only valid acts of the spirit in movement.

A project of this type reveals the dual nature of the image for the avant-gardes. First, there is the surging nature of the Dada image, an image nearly in its raw state, the one defended by Tzara for whom "La pensée se fait dans la bouche" ("Dada Manifeste" 379) 'Thought is made in the mouth' ("Dada Manifesto" 35). And secondly, there is the finer, more symbolic nature defined by Breton in L'Amour fou: "La beauté convulsive sera érotique-voilée, explosante-fixe, magiquecirconstancielle ou ne sera pas" (26) 'Convulsive beauty will be veiled-erotic, fixed-explosive, magic-circumstantial, or it will not be' (Mad Love 19).

In short, in Cinéma 33 Sernet assembled one last time at the patient's bedside the best doctors to deliver a final diagnosis on the state of the avant-gardes and the image. Afterward, each went off in his own direction as history gradually closed in upon the European avant-gardes, shrouding them from view.

Europe, fatalistic, was once again preparing for war. Over the years, countless local conflicts had patiently fueled the approaching incendiary. The artists held their breath along with everyone else. Little by little, the hopes and rebellions of an entire generation were being smothered. Resigned, depressed, apprehensive, 
Europeans waited and prepared for the worst, the Roaring Twenties now far behind. When Sernet managed to place occasional poems through sheer tenacity, he now published in less provocative journals: Le Journal des Poètes, Le Phare de Neuilly, Les Nouvelles littéraires.

In 1937, he published at his own expense his first collection of poems: Commémorations, which resonates throughout with a universal pessimism. In 1938, a new publication followed, Un Jour et une nuit. Events were already sliding toward horror and its cohort of unbearable images. His revolt grew more muted, his pessimism deepened, and he struggled to contain the collective and personal difficulties that assailed him. In February 1938, he managed to obtain French nationality. In October 1939, at the very beginning of the hostilities, he was mobilized at the age of 37. In June 1940, he was captured at Sedan. Thus began a long period of migration from one prisoner-of-war camp to another. He decided to break his captivity to avoid being transferred to Germany. In May 1941, he escaped from the Pure Camp in the Ardennes.

Back in Paris, he rediscovered the precariousness of life in France under the Occupation. But above all, as a newly naturalized French citizen and recent escapee, he feared possible arrest, especially given his Jewish origins. Sernet decided then to slip into the "Zone sud." In this so-called "free" zone, governed by the pro-German Vichy regime, he received help from his poet friends in Rodez. He settled in the isolated village of Bizanet. From this new place of exile, he submitted critical articles on poetry to the Méridien review, while continuing to write his own poetry. He also participated in a number of multi-author collections which mark the literary resistance under the Nazi Occupation. At the time of the Liberation, he published in L'Honneur des poètes and L'Éternelle Revue. More than ever, Sernet strove to understand the sadness and tragedy of life.

In 1945, after the Liberation of France, Sernet became involved in the movement for peace, joining other engaged poets, all veterans of the underground struggle who were joining the French Communist Party to contribute to Aragon's famous newspaper, Les Lettres françaises. This marked a turning point for Sernet, who now set out to get his work into print, first in non-commercial venues, then after 1950, at Éditions Seghers, which published eleven volumes of his poetry.

Claude Sernet then fell into a state of suffering, which he called the state of the pariah and from which he would never escape. Gradually, his poetry took the form of a tenacious elegy that spoke of existential pain and a melancholic state of the spirit. He is one of the few poets to have joined an artistic current more common to the playwrights of the absurd, like Ionesco or Beckett, even the theorist of absurd man, Albert Camus. And in the emerging postwar period, a new economic and political order was being established. Sernet was now almost fifty years old.

Translated from the French by Lynn Palermo 


\section{Works Cited}

Adamov, Arthur. L'Homme et l'enfant. Paris: Gallimard, 1968. Print.

Adamov, Arthur, Fernand Lumbroso, and Claude Sernet. Mises au point. Paris: Discontinuité, 1929. Print.

Barthes, Roland. "Literature and Discontinuity." Critical Essays. Trans. Richard Howard. Evanston: Northwestern UP, 1972. 171-83. Print.

—. "Littérature et discontinu." 1962. CEuvres complètes. Vol. 1. Paris: Seuil, 1993. 1299-1308. Print.

Bataille, Georges. Eroticism. Trans. Mary Dalwood. London: Calder, 1962. Print. - L'Érotisme. Paris: Minuit, 1957. Print.

Bouloc, Denys-Paul. Ilarie Voronca. Rodez: Subervie, 1961. Print. Visages de ce temps 8.

Breton, André. L'Amour fou. 1937. Paris: Gallimard, 1976. Print. Collection Folio 723.

_. Mad Love. Trans. Mary Ann Caws. Lincoln: U of Nebraska P, 1987. Print. French Modernist Library.

Daumal, René. "Projet de présentation du Grand Jeu." Le Grand Jeu. Ed. Marc Thivolet. Paris: L'Herne, 1968. 17-18. Print. L'Écriture des vivants 2. Cahiers L'Herne 10.

Discontinuité. “L'Aube n’est pas une épée.” Discontinuité 1 (June 1928): n. pag. Print.

Fondane, Benjamin. "Cinéma 33." Cahiers jaunes 4 (1933): 12-20. Print.

Gourdet, Michel. "Claude Sernet: L'Homme et l'œuvre." Thèse de $3^{\text {e }}$ cycle U de Nice, 1977. Print.

Hyde, John Kenneth. Benjamin Fondane: A Presentation of His Life and Works. Geneva: Droz, 1971. Print. Histoire des idées et critique littéraire 112.

MacOrlan, Pierre. Petit Manuel du parfait aventurier. Paris: La Sirène, 1920. Print. Les Tracts.

Manifestations au studio des Ursulines . . [flyer]. N.p.: n.p., [1929]. Flickr. Web. 9 Apr. 2014. <https://www.flickr.com/photos/camino440/6893515992/>.

Morand, Paul. Bucarest. Paris: Plon, 1935. Print.

Navel, Georges. Travaux: Récit. Paris: Stock, 1969. Print.

Pierre-Quint, Léon. "Le Grand Jeu ou un signe dans l'avenir." Les Nouvelles littéraires (6 Oct. 1928): 4. Print.

Sernet, Claude, ed. Cinéma 33. Spec. issue of Cahiers jaunes 4 (1933). Print.

Sernet, Claude. Les Pas recomptés. Paris: Seghers, 1962. Print.

- Preface. L'Exode super flumina Babylonis. By Benjamin Fondane. Paris: Fenêtre ardente, 1965. 7-10. Print.

- Preface. Les Premiers Poèmes. By Tristan Tzara. Trans. Claude Sernet. Paris: Seghers, 1965. 7-9. Print. 
Tzara, Tristan. "Dada Manifeste sur l'amour faible et l'amour amer." 1921. CEuvres complètes. Ed. Henri Béhar. Vol. 1. Paris: Flammarion, 1975. 377-89. Print.

- "Dada Manifesto on Feeble Love and Bitter Love." His Seven Dada Manifestos and Lampisteries. Trans. Barbara Wright. London: Calder; New York: Riverrun P, 1992. 31-48. Print.

Voronca, Ilarie. La Poésie commune. Paris: Plasma, 1979. Print.

Copyright (C) 2015 Michel Gourdet 